\title{
INFLUENCE OF RANGE LAND OF THE SETTLED CAMP OF GERS ON LIVESTOCK HEALTH AND FOOD SECURITY
}

\author{
Ts.Byambajav ${ }^{1}$, Ch.Buyantogtokh ${ }^{1}$, Ts.Javzandolgor ${ }^{1}$, Ts.Munkhtuul ${ }^{1}$, S.Bolorchuluun ${ }^{1}$, \\ Ts.Amartaivan², B.Batzorig ${ }^{3}$, Ya.Ganbold ${ }^{1}$ \\ 1 - Mongolian State University of Agriculture, Institute of Veterinary Medicine \\ 2 - National University of Mongolia, Center for Nuclear Research \\ 3 - State Central Veterinary Laboratory \\ chbuyan@yahoo.com
}

KEY WORDS: settled camp of gers, soil, plantation, water, micro element and heavy metal

Purpose: In this research we have determined impact of activities of the settled herders on soil, water and plantation of degraded pasture land caused by distortion of technology of cattle breeding, content of some chemicals in blood serum of livestock as well as plantation number and cover.

Conclusions: 1. Grazing crop of the settled camp of gers is less by 3-6 species and cover size is less by 8-10 percent compared to the control area.

2. It has been determined that content of $\mathrm{Cu}, \mathrm{Co}, \mathrm{Se}, \mathrm{Pb}$ in soil and plant of pasture land of the settled camp of gers in close pasture land $\mathrm{Zn}, \mathrm{Fe}$ is the least in close and middle pasture lands and the most in remote pasture land.

3. Copper contained in water is higher by $0.132 \mathrm{ppm}$ than the internationally accepted highest level, zinc is less by 0.233 ppm and iron, cobalt, selenium and lead is 2-7 times more than the permissible highest level.

4. Copper, zinc, cobalt and iron contained in the blood serum of the livestock of the settled camp of gers is less than normal psychological amount and selenium and lead are higher than the permissible amount.

5. Much heavy metal contained in soil, water and plant of the close pasture land of the settled camp of gers is determined by much content of selenium and lead in the serum that may affect food security and social health.

\section{INTRODUCTION}

As Mongolia is exposed to the climatic change more its impacts have been clearly detected on livestock health and herd quality and have been observed in their habitat more. On the other hand, with regard to changes to the social trend of Mongolia and transition of herders to settled life from traditional way of life they have lost their selected method to use remote land following transparent water and fresh range land and preferring their comfortable living and moving 2-4

times per year including winter place-summer camp, winter place-spring quarter-summer camp, winter place-summer camp-autumn quarter. Also there are not few "settled camp of gers" that settles down on one winter place for 4 seasons [2]. In developing countries most percent of the population is dependent on animal husbandry but study on mutual dependence of climatic changes and animal husbandry has been forgotten at all [19]. 
Movement from the countryside to the urban place has been going rapidly and demands for the livestock products will be increased along with it [8].

Growing period of grazing crop of Mongolia is 150 days and range land based animal husbandry is run mainly thus it belongs to dry and half dry range land system according to the classification of Steinfeld and others. Climatic change impacts on the dry and half dry range land system more than other systems. Those impacts include decrease in harvest amount and water supply, change in occurrence and spread of human, livestock and plant diseases, change in the disease transmitter, change in the biodiversity, changes in living, livelihood and subsistence and other direct impacts. The most urgent issue from them is to influence in the human health through livestock originated foods [14].

However average warmth of Mongolia has increased by $2.14^{\circ} \mathrm{C}$ for recently frost momentum is increased in winter. According to the surface water count 852 from 5128 rivers, 2277 from 9306 streams and natural spa, 1181 from 3747 lakes and ponds have been dried out. Study on intensity of impacts on regions in the vicinity of Inner Mongolia and Baikal, Russian Federation and animal husbandry, forest steppe and steppe regions of Mongolia has determined that hygrophyte plants have been decreasing and xerophyte plants have been increasing. So productivity has decreased by 1.4-7.0 \% [16].

When various livestock is on own appropriate range land, it has been breeding normally and its productivity is stable. In some places livestock productivity is less, growth is slow and much perish due to disease. It depends on how the livestock got used to the growth stages, species and chemical content of grazing crop, chemical component of soil and water and climatic condition of that particular land.

On the other hand as Mongolia has been affected by the global warmth and climatic changes its impacts have been more impacting on livestock health and their living and habitat changes. In other words due to peculiar feature of particular land endemic disease that commonly occurs among the range land livestock not only occurs in the livestock but also except for human sickness of that land it becomes endemic disorder caused by plants and common occurrence of poisoning [4]. Cobalt supports hemogenesis and carbohydrate and minerals exchange. When the organism is lack of cobalt it causes abnormalities including anaemia, loss of appetite and emaciation. Selenium is included in component of glutationperooxidase ferment and it decomposes hyper oxide and prevents necrosis and degeneration. Copper is a micro element that plays important role on hemogenesis and osteal generation and hair and wool growth and it is included in component of many enzymes including cytochrome oxidase, tyrosinase, ceruloplasmin and galactose oxidase so it participates in all kinds of metabolisms and tissue breath. Copper deficiency causes abnormalities including anaemia, slowness in growth, degeneration of brain and spinal tissues and hair and wool become white [4]. Disease caused by copper deficiency is called "orongi" in Mongolian. It is revealed by serious and light forms and $40-60 \%$ of lambs of farm where this disease spreads is perished and 80$90 \%$ of sick new born young animals is dead [1]. Anaemia is caused by deficiency of iron, copper, cobalt and manganese in fodder which are micro elements that participate and activate hemogenesis [3]. Zinc is accumulated in bone, skin and hair of the livestock in most amounts. Zinc is included in structure of carbonic anhydrase, pancreatic carboxypeptidase, glutamine, dehydrogenase enzyme of lactic acid. Also except for activating other enzymes $75 \%$ of total zinc in the organism is located in red corpuscle and integrates carbonic acid gas in it and releases from the body. Therefore, when zinc is lacking disorders including slowness in growth, skin exfoliation and inflammation, natural abortion, abnormal young animal and weak living ability of the young animal occur. Lead is toxic substance that impacts almost all organs and system and pollutes environment and it affects mentality, kidney, blood formation and reproductive system [13]. Lead is called nervous poison and it is dangerous to slow down and delay child growth and brain development. Selenium compounds that dissolve easily in water more poisonous than the compounds that dissolve with great difficulty [15]. Micro elements are important elements that are regulated by physiological mechanism as well as they can cause serious damage to human and livestock health if their regulation is lost. In particular we can mention zinc here [9].

We have conducted this work due to proper requirement to study and determine impacts of the range land degradation caused by the climatic change, global warmth, activities of the settled herders and technological distortion in livestock breeding on the soil, water, plant, content of some chemicals contained in the livestock blood serum, number of plant species and its cover. 


\section{RESEARCH MATERIALS AND METHODOLOGY}

We have selected the settled camp of gers in Yoruu soum, Selenge aimag and divided range land into 3 zones. We have randomly selected $1 \mathrm{~m}^{2}$ area within $250 \mathrm{~m}^{2}$ land within the range land that can represent soil, water and plant of $1^{\text {st }}$ zone or close range land (within $0.5-2 \mathrm{~km}$ circle), $2^{\text {nd }}$ zone or medium distance range land (within $3-5 \mathrm{~km}$ circle) and $3^{\text {rd }}$ zone or remote range land (within 8$10 \mathrm{~km}$ circle). We used 1-3 kg of plant sample, 3-5 $\mathrm{kg}$ of soil sample, 21 water sample from each point selected three times in June, 2011 - 2013 and the blood serum of 128 livestock including 30 he goats, 30 she goats, 30 rams, 30 ewes and 18 cows of that settled camp of gers for the analysis and research work. Also content of some chemicals have been determined in 45 soil samples, 45 plant samples, 10 water samples totaling 221 samples by full reflection X-ray fluorescence spectrometer. We have carried out the analysis by diluting blood serum covered by the analysis by 10 times, carbonizing $5 \mathrm{gr}$ plant sample at $150^{\circ} \mathrm{C}$, turning to ash completely at $500^{\circ} \mathrm{C}$ and transferring it into solution form.

Results and discussion: 1. Plantation of mountain steppe, flood plain and river valley has been dominated within the range land of the settled camp of gers.

As for plant species and cover of grazing crop of the settled camp of gers there are 3 species of plant with $42 \%$ cover including $C$. duriuscula, $A$. firgidia, $P$. anserine within $1 \mathrm{~m} 2$ area in close range land $(500 \mathrm{~m})$ and 6 species of plant including $S$. squarrosa, K. macrantha, S. sibirica, C. duriuscula, A. frigida, P.acaulis and plant cover in the vicinity of winter place of the settled camp of gers or control area is $51 \%$.

7 species of plants with $47 \%$ cover including $S$. squarrosa, K. macrantha, S. krylovii, $S$. sibirica, C. duriuscula, A. frigida, $P$. acaulis 3 within $1 \mathrm{~m} 2$ area in medium distance range land $(3000 \mathrm{~m})$ have been registered and 11 species with 57\% including S. krylovii, A.cristatum, $P$. bifurca, $C$. duriuscula, S. squarrosa, A. frigida, A. adamsii, $P$. acaulis, $A$. firgidia, $K$. prostrata, $F$. sibiricum registered within the control area.

10 plants including $K$. macrantha, S.krylovii, S. squarrosa, S. sibirica, C. duriuscula, $A$. frigida, $P$. bifurca, A. adamsii, $P$. acaulis, A firgidia 3 with $54 \%$ cover have grown within $1 \mathrm{~m} 2$ area in remote range land. Then 15 species of plants including $S$. squarrosa, S. sibirica, $S$. baicalensis, $K$. macrantha, A. cristatum, A. frigida, $P$. acaulis, $F$. sibiricum, $C$. duriuscula, A. odorum, A. adamsii, $K$. prostrata, $P$. anserine, P.turczaninovii, $P$. lanacetifolia with $62 \%$ cover have grown in the control zone.

Content of some micro and macro elements have been determined in the plant samples prepared from the selected points of the range land of the settled camp of gers (Table 1).

Amount of some chemicals contained in grazing crop (ppm)

\begin{tabular}{|c|c|c|c|c|}
\hline $\begin{array}{c}\text { Name of micro } \\
\text { organism }\end{array}$ & $\begin{array}{l}\text { Close range } \\
\text { land }\end{array}$ & $\begin{array}{c}\text { Medium } \\
\text { distance range } \\
\text { land }\end{array}$ & $\begin{array}{l}\text { Remote range } \\
\text { land }\end{array}$ & $\begin{array}{c}\text { V.V.Kovalskii, } \\
1970\end{array}$ \\
\hline Copper $(\mathrm{Cu})$ & $0.386 \pm 0.01$ & $0.751 \pm 0.012$ & $12.53 \pm 1.01$ & 3-12 мг/кг \\
\hline Zinc (Zn) & $1.242 \pm 0.02$ & $1.127 \pm 0.02$ & $7.786 \pm 0.91$ & 20-60 мг/Кг \\
\hline Iron $(\mathrm{Fe})$ & $1.344 \pm 0.02$ & $0.684 \pm 0.01$ & $5.962 \pm 0.62$ & 24-30 мг/кг \\
\hline Cobalt $(\mathrm{Co})$ & $0.266 \pm 0.01$ & $0.352 \pm 0.01$ & $0.454 \pm 0.01$ & $0.25-1.0$ мг/кГ \\
\hline Selen (Se) & $0.192 \pm 0.01$ & $0.27 \pm 0.01$ & $0.286 \pm 0.01$ & 0.1-2.0 мг/кг< \\
\hline Lead $(\mathrm{Pb})$ & $0.309 \pm 0.01$ & $0.383 \pm 0.01$ & $1.193 \pm 0.002$ & $\begin{array}{l}\text { 90-300 EU Stand } \\
100 \text { MN Stand }\end{array}$ \\
\hline
\end{tabular}

According to the results of the analysis content of $\mathrm{Cu}, \mathrm{Zn}, \mathrm{Fe}, \mathrm{Co}, \mathrm{Se}, \mathrm{Pb}$ is $0.386 ; 1.242 ; 1.344 ; 0.266$ ; 0.192; $0.309 \mathrm{ppm}$ in sample of plantation cover o $\mathrm{f}$ the close rangeland of the settled camp of gers, 0 $.751 ; 1.127 ; 0.684 ; 0.352 ; 0.27 ; 0.383 \mathrm{ppm}$ in mediu $\mathrm{m}$ distance range land and $12.53 ; 7.786 ; 5.962 ; 0.4$
54; $0.286 ; 1.193 \mathrm{ppm}$ in remote range land. It is eq ual and less compared to the copper content conta ined in grazing crop determined by the researchers [3] Co, Se at normal and $\mathrm{Zn}, \mathrm{Fe}, \mathrm{Pb}$ amount is less than normal level. 
2. Results taken soil sample from the selected secti on of that range land and determined some micro elements and heavy metal contained in it are show n below (Table 2).

Content of some micro elements and heavy metal contained in the range land soil, ppm

Table 2

\begin{tabular}{lrrrc}
\hline Micro element & \multicolumn{1}{c}{$\begin{array}{c}\text { Close range } \\
\text { land }\end{array}$} & $\begin{array}{c}\text { Medium } \\
\text { distance range } \\
\text { land }\end{array}$ & $\begin{array}{c}\text { Remote range } \\
\text { land }\end{array}$ & Permissible value, mg/kg \\
\hline Copper $(\mathrm{Cu})$ & $0.84 \pm 0.01$ & $0.906 \pm 0.012$ & $1.905 \pm 0.001$ & $24.7-38.0^{+}$ \\
Zinc $(\mathrm{Zn})$ & $4.416 \pm 0.02$ & $3.594 \pm 0.002$ & $4.599 \pm 0.312$ & $60^{+}$ \\
Iron $(\mathrm{Fe})$ & $1130.685 \pm 0.9$ & $332.937 \pm 0.9$ & $656.604 \pm 0.9$ & No information \\
Cobalt $(\mathrm{Co})$ & $1.581 \pm 0.02$ & $2.913 \pm 0.01$ & $4.224 \pm 0.01$ & $50 \mathrm{MNS}$ \\
Selenium $(\mathrm{Se})$ & $0.456 \pm 0.01$ & $0.774 \pm 0.01$ & $2.679 \pm 0.01$ & $10 \mathrm{MNS}$ \\
Lead $(\mathrm{Pb})$ & $0.528 \pm 0.01$ & $1.224 \pm 0.01$ & $2.541 \pm 0.01$ & $90-300$ EUStand [7,10,11] \\
& & \multicolumn{2}{c}{ Norm in the soil of Mongolia [5] }
\end{tabular}

According to the above table content of $\mathrm{Cu}, \mathrm{Co}, \mathrm{S}$ $\mathrm{e}, \mathrm{Pb}$ is increased in the remote range land compar ed to the close range land while zinc has no much difference and iron is not stable.

According to the result of the above research it is 1 ess than the zinc amount [4] in the soil of other ai mags (Arkhangai 54 \pm 14 , Bayankhongor $60 \pm 12$, Z avkhan $63 \pm 2 \mathrm{mg} / \mathrm{kg}$ ) but it has not reached to the deficiency amount $(<3 \mathrm{mg} / \mathrm{kg})$ and $\mathrm{Cu}$, Co and $\mathrm{Se}$ amount is less.

3. Results of the study determined amount of som e micro elements and heavy metal contained in the blood serum of cow, sheep and goat of the settled camp of gers (Table 3).

Results determined some micro elements and heavy metal contained in the serum, ppm

Table 3

\begin{tabular}{|c|c|c|c|c|c|c|}
\hline \multirow[b]{2}{*}{$\begin{array}{l}\text { Name of micro } \\
\text { organism }\end{array}$} & \multicolumn{2}{|c|}{ Goat } & \multicolumn{2}{|c|}{ Sheep } & \multirow{2}{*}{$\begin{array}{l}\text { Cow } \\
\mathrm{n}=18\end{array}$} & \multirow{2}{*}{$\begin{array}{l}\text { Normal } \\
\text { amount }\end{array}$} \\
\hline & $\begin{array}{l}\text { Female } \\
\mathrm{n}=30\end{array}$ & Male $n=30$ & $\begin{array}{l}\text { Female } \\
\mathrm{n}=30\end{array}$ & Male $n=30$ & & \\
\hline Copper $(\mathrm{Cu})$ & $83.9 \pm 2.1$ & $60.1 \pm 1.25$ & $97.9 \pm 3.11$ & $88.8 \pm 3.25$ & $75.7 \pm 3.22$ & $\begin{array}{l}{ }^{\mathrm{x}} 1000- \\
1300\end{array}$ \\
\hline Zinc (Zn) & $105.6 \pm 3.2$ & $82.7 \pm 2.35$ & $112.8 \pm 4.21$ & $114.8 \pm 4.21$ & $81.0 \pm 3,32$ & r $800-1400$ \\
\hline Iron $(\mathrm{Fe})$ & $124.4 \pm 0.08$ & $169.1 \pm 0.6$ & $204.3 \pm 0.24$ & $135 . \pm 0.24$ & $\begin{array}{c}222.0 \pm 0.4 \\
5\end{array}$ & $\begin{array}{l}\mathrm{Y} 130000- \\
250000\end{array}$ \\
\hline Cobalt (Co) & $41.5 \pm 0.05$ & $26.1 \pm 0.4$ & $37.9 \pm 0.06$ & $46.9 \pm 0.06$ & $42.7 \pm 0.06$ & ${ }^{\mathrm{x}} 100-120$ \\
\hline Selen (Se) & $33.0 \pm 0.1$ & $26.7 \pm 0.05$ & $30.9 \pm 0.05$ & $39.4 \pm 0.06$ & $53.2 \pm 0.2$ & Ү $0.07-0.1$ \\
\hline Lead $(\mathrm{Pb})$ & $57.4 \pm 2.2$ & $53.7 \pm 0.13$ & $53.7 \pm 0.09$ & $61.5 \pm 0.08$ & $58.2 \pm 0.09$ & ${ }^{+} 0.05-0.23$ \\
\hline
\end{tabular}

+ - V. Rajaganapathy, 2011 [17], ${ }^{\mathrm{Y}} \mathrm{cow}$ - Anderson, D. E., 2009 [6], ${ }^{\mathrm{x}}$ sheep - A.Sodnomdarjaa and other 
According to the results of the above analysis con tent of $\mathrm{Cu}, \mathrm{Zn}, \mathrm{Fe}, \mathrm{Co}$ in blood serum of sheep, go at and cow is $60.1-97.9 ; 81.0-114.8 ; 135.9-222.0 ; 2$ 6.1-46.9 or lacking and $\mathrm{Se}, \mathrm{Pb} 26.7-53.2 ; 53.7-61.5$ ppm or redundant. According to the determinatio $\mathrm{n}$ by researchers [3] copper amount in the serum is less by 2-3 times compared to the normal amount and it has been determined copper deficiency. Res ult of our research which determines 10-16 times 1 ess amount proves potential occurrence of copper deficiency.

4. We have taken sample from small tribut ary of Yoruu river or water where livestock of tha $\mathrm{t}$ settlement drinks water and used it as research $\mathrm{m}$ aterial (Table 4).

Content of some chemicals contained in water (ppm)

Table 4

\begin{tabular}{l|c|cccc}
\hline & \multirow{2}{*}{$\begin{array}{c}\text { Amount } \\
\text { Name of micro } \\
\text { organism }\end{array}$} & \multicolumn{4}{|c}{ Permissible value, mg/l } \\
& contained in & & \multicolumn{4}{c}{} \\
\cline { 3 - 6 } & water & Mongolia & WHO & USA & EU \\
\hline Copper $(\mathrm{Cu})$ & $1.132 \pm 0.02$ & 1.0 & 2 & 1.3 & - \\
Zinc $(\mathrm{Zn})$ & $0.767 \pm 0.001$ & 1.0 & $5-15$ & 5 & 2 \\
Iron $(\mathrm{Fe})$ & $1.353 \pm 0.02$ & - & 0.3 & - & 0.2 \\
Cobalt $(\mathrm{Co})$ & $0.484 \pm 0.001$ & - & - & - & - \\
Selenium $(\mathrm{Se})$ & $0.346 \pm 0.001$ & - & 0.01 & - & - \\
Lead $(\mathrm{Pb})$ & $0.728 \pm 0.01$ & - & $0.1-0.05$ ppm & - & - \\
\hline
\end{tabular}

While accepted highest amount of copper contained in water is $1 \mathrm{ppm}$ and it is higher by 1.1 $32 \mathrm{ppm}$ or $0.132 \mathrm{ppm}$ and zinc is less by $0.233 \mathrm{ppm}$
, iron, cobalt, selenium and lead is 2-7 times more than the accepted highest amount according to ou $r$ measurement.

\section{CONCLUSION}

Grazing crop of the settled camp of gers is less by 3-6 species and cover size is less by 8-10 percent co mpared to the control area and it shows degradati on of range land.

2. It has been determined that content of $\mathrm{Cu}, \mathrm{Co}$, $\mathrm{Se}, \mathrm{Pb}$ in soil and plant of pasture land of the settl ed camp of gers in close pasture land $\mathrm{Zn}, \mathrm{Fe}$ is the least in close and middle pasture lands and the mo st in remote pasture land

3. Copper contained in water is higher by $0.132 \mathrm{pp}$ $\mathrm{m}$ than the internationally permitted highest level, zinc is less by $0.233 \mathrm{ppm}$ and iron, cobalt, seleniu $\mathrm{m}$ and lead is $2-7$ times more than the permissible highest level

4. Copper, zinc, cobalt and iron contained in the $b$ lood serum of the livestock of the settled camp of gers is less than normal psychological amount and selenium and lead are higher than the permissible amount.

5. Much heavy metal contained in soil, water and plant of the close pasture land of the settled camp of gers is determined by much content of selenium and lead in the serum that may affect food securit $\mathrm{y}$ and social health.

\section{REFERENCES}

1. Batchuluun C., "Etiology, treatment and som e prevention methods of Orongi disease" thesis of Doctor of Veterinary Medicine. UB., 1995

2. "Diagnosis and Drug preparation of Biogeocenos dependent disease" Science \& Technological project report. 2013.

3. Livestock's endemic disease. Color atlas, 2012

4. Sodnomdarjaa A, Sodnomdarjaa R.,

Erdenetsetseg S. Mongolian livestock's endemic disease. UB. 2012

5. Quality of soil. Contaminating compounds of soil and their permitted highest level, MNS 5850:2008

6. Anderson, D. E. and Rings M. (2009) Current Veterinary Therapy: Food Animal Practice St. Louis, MO: Saunders Elsevier. 
7. David O. Olukanni, David O. Adeoye, Heavy Metal Concentrations in Road Side Soils from Selected Locations in the Lagos Metropolis, Nigeria, International Journal of Engineering and Technology Volume 2 No. 10, October, 2012 ISSN: 2049 -3444 (C) 2012-

http://ietjournals.org/archive/2012/oct_vol_2_no_10/2 947831345468995.pdf

8. Delgado C., 1999, Livestock to2020: www.ifri.org/sites/default/files/publications/vb 61.pdf

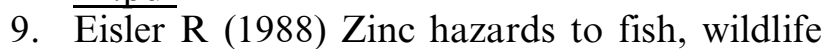
and invertebrates: A synoptic review. US Fish Wildlf Survev Reprod Biol 85:1-6

10. ftp://ftp.fao.org/docrep/fao/010/a1445e/a1445 e03.pdf

11. ftp://ftp.fao.org/docrep/fao/010/A0701E/A070 $1 \mathrm{E} 00 . \mathrm{pdf}$

12. http://www.lenntech.com/who-eu-waterstandards.htm

13. http://www.ubhealth.mn/index.php/2011-1101-01-56-50/60-2011-03-28-02-58-20/4962011-10-21-02-54-39.html
14. IPCC, 2007, Climate change 2007: http://www.ipcc.cs/SPM13apr07.pdf

15. Mehjbeen Javed and Nazura Usmani, Assessment of heavy metal $(\mathrm{Cu}, \mathrm{Ni}, \mathrm{Fe}, \mathrm{Co}$, $\mathrm{Mn}, \mathrm{Cr}, \mathrm{Zn})$ pollution in effluent dominated rivulet water and their effect on glycogen metabolism and histology of Mastacembelus armatus, Springerplus. 2013; 2: 390.

16. "Mongolia Assessment Report on Climate Change 2009", Ulaanbaatar, 2010, pp. 228

17. V. Rajaganapathy, F. Xavier, D. Sreekumar and P.K. Mandal, 2011. Heavy Metal Contamination in Soil, Water and Fodder and their Presence in Livestock and Products: A Review. Journal of Environmental Science and Technology, 4: 234-249.

18. Steinfeld H. et al., Livestock's long shadow: FAO, Italy, 2007, pp. 37-54

19. Thornton P.K., The impacts of climate change on livestock and livestock systems in developing countries: A review of what we know and what we need to know, 2009, www.elsevier.com/locate/agsy 